\title{
Virological remission after antiretroviral therapy interruption in female African HIV seroconverters
}

\author{
Morgane Gossez ${ }^{\mathrm{a}}$, Genevieve Elizabeth Martin ${ }^{\mathrm{a}}$, Matthew Pace ${ }^{\mathrm{a}}$, \\ Gita Ramjee $^{b}$, Anamika Premraj ${ }^{b}$, Pontiano Kaleebuc, Helen Rees ${ }^{\text {d, }}$ \\ Jamie Inshaw ${ }^{\mathrm{e}}$, Wolfgang Stöhr ${ }^{\mathrm{e}}$, Jodi Meyerowitz ${ }^{\mathrm{a}}$, Emily Hopkins ${ }^{\mathrm{a}}$, \\ Mathew Jones ${ }^{\mathrm{a}}$, Jacob Hurst ${ }^{\mathrm{a}}$, Kholoud Porter ${ }^{\mathrm{f}}$, Abdel Babikere, \\ Sarah Fidler', John Frater $^{\mathrm{a}, \mathrm{h}, \mathrm{i}}$, on behalf \\ of the SPARTAC Trial Investigators
}

\begin{abstract}
Introduction: There are few data on the frequency of virological remission in African individuals after treatment with antiretroviral therapy (ART) in primary HIV infection (PHI).

Methods: We studied participants $(n=82)$ from South Africa and Uganda in Short Pulse Antiretroviral Treatment at HIV-1 Seroconversion, the first trial of treatment interruption in African individuals with PHI randomized to deferred ART or 48 weeks of immediate ART. All were female and infected with non-B HIV subtypes, mainly C. We measured HIV DNA in $\mathrm{CD}^{+}{ }^{+}$T cells, $\mathrm{CD} 4^{+}$cell count, plasma viral load (pVL), cell-associated HIV RNA and T-cell activation and exhaustion. We explored associations with clinical progression and time to $\mathrm{pVL}$ rebound after treatment interruption $(n=22)$. Data were compared with nonAfrican Short Pulse Antiretroviral Treatment at HIV-1 Seroconversion participants.

Results: Pretherapy $p V L$ and integrated HIV DNA were lower in Africans compared with non-Africans (median 4.16 vs. $4.72 \log _{10}$ copies/ml and 3.07 vs. $3.61 \log _{10}$ copies/ million $\mathrm{CD}^{+} \mathrm{T}$ cells, respectively; $\left.P<0.001\right)$. Pre-ART HIV DNA in Africans was associated with clinical progression $\left(P=0.001, \mathrm{HR}\right.$ per $\log _{10}$ copies/million $\mathrm{CD}^{+} \mathrm{T}$ cells increase $(95 \% \mathrm{Cl}) 5.38(1.95-14.79))$ and time to $\mathrm{pVL}$ rebound $(P=0.034$, HR per $\log _{10}$ copies/ml increase $\left.4.33(1.12-16.84)\right)$. After treatment interruption, Africans experienced longer duration of viral remission than non-Africans $(P<0.001 ; \mathrm{HR}$ 3.90 (1.75-8.71). Five of 22 African participants (22.7\%) maintained VL less than 400 copies/ml over a median of 188 weeks following treatment interruption.
\end{abstract}

Conclusion: We find evidence of greater probability of virological remission following treatment interruption among African participants, although we are unable to differentiate between sex, ethnicity and viral subtype. The finding warrants further investigation.

Copyright (๑) 2018 The Author(s). Published by Wolters Kluwer Health, Inc.

AIDS 2019, 33:185-197

Keywords: Africa, antiretroviral therapy, HIV, posttreatment control, remission, treatment interruption

\footnotetext{
${ }^{a}$ Peter Medawar Building for Pathogen Research, Nuffield Department of Medicine, Oxford, UK, bHIV Prevention Research Unit, South African Medical Research Council, Durban, South Africa, ${ }^{\mathrm{C}}$ Medical Research Council/Uganda Virus Research Institute, Entebbe, Uganda, ${ }^{d}$ Wits Reproductive Health and HIV Institute of the University of the Witwatersrand, Johannesburg, South Africa, ${ }^{\mathrm{e} M R C}$ Clinical Trials Unit at UCL, Institute of Clinical Trials \& Methodology, ${ }^{f}$ Institute for Global Health, University College London, ${ }^{\mathrm{g}}$ Division of Medicine, Wright Fleming Institute, Imperial College, London, ${ }^{\mathrm{h}}$ The Oxford Martin School, and ${ }^{\mathrm{i}} \mathrm{Oxford}$ National Institute of Health Research Biomedical Research Centre, Oxford, UK.

Correspondence to John Frater, FRCP, PhD, Peter Medawar Building for Pathogen Research, Nuffield Department of Medicine, University of Oxford, Oxford, UK.
}

Tel: +44 1865 271288; fax: +44 1865 281890; e-mail: john.frater@ndm.ox.ac.uk Received: 29 March 2018; accepted: 13 September 2018. 


\section{Introduction}

There is no cure for HIV infection despite effective antiretroviral therapy (ART). Latently infected $\mathrm{CD} 4^{+} \mathrm{T}$ cells [1] persist despite ART and decay slowly [2]. Most people living with HIV (PLHIV) experience viral reactivation soon after ART interruption. However, studies of individuals who initiate ART early in primary HIV infection (PHI) have identified more rapid clearance of the reservoir [3-5] and cases of virological remission [6-8].

As new strategies are developed to target the HIV reservoir [9], there has been an increase in the number of treatment interruption studies raising concerns over safety [10-12]. An algorithm to predict individuals who might sustain undetectable plasma viral loads ( $\mathrm{pVL}$ ) after treatment interruption would therefore be of benefit. In SPARTAC (Short Pulse Antiretroviral Treatment at HIV-1 Seroconversion) [13], HIV DNA levels in $\mathrm{CD}^{+} \mathrm{T}$ cells [14] and expression of immune checkpoint receptors PD-1, Tim-3 and Lag-3 [15] predicted time to pVL rebound after treatment interruption. Cell-associated HIV RNA (CARNA) [16] - a marker of a more inducible reservoir - and the frequency of viral blips on ART [17] have also been shown to predict rebound viraemia.

Most studies examining the HIV reservoir investigate European or North American participants infected with subtype B HIV. This is not representative of the global burden of disease, given that $70 \%$ of PLHIV are in Africa and $50 \%$ of prevalent HIV infections are estimated to be due to subtype C [18]. Whereas non-B viral subtypes respond well to ART [19], our current understanding of the reservoir may not translate to African or non-B infected populations, especially as variation in $\mathrm{pVL}$, HIV DNA and CD4 ${ }^{+}$T-cell count is linked to ethnicity and geography [20]. There may also be differences between both sex and HIV subtypes relating to replicative fitness, biology of transmission and disease progression [21-26]. We turned to SPARTAC to analyse outcomes after treatment interruption in African participants.

\section{Methods}

\section{Participants and trial design}

The design of the SPARTAC trial is reported elsewhere [13]. SPARTAC was an international RCT of early ART, comparing 12 or 48 weeks of ART followed by treatment interruption with no immediate treatment. Three hundred and sixty-six adults within an estimated 6 months from seroconversion were recruited. All participants gave written informed consent (see Supplementary Material for details of ethics approvals, http:// links.lww.com/QAD/B378). The primary endpoint was a composite of a CD4 ${ }^{+}$T-cell count of less than 350 cells/ $\mu l$ or initiation of long-term ART. Time of virological failure was defined as the first of two consecutive values of plasma viral load above 400 copies/ml. HIV RNA was measured at clinical sites by the Bayer (Chiron bDNA) assay [13]. We restricted our analysis to participants who received either no ART or 48 weeks of ART. SPARTAC also recruited to a 12-week ART arm in which participants responded similarly to the untreated arm $[8,13]$, so we have not included these participants in this substudy.

African participants for this substudy were women from Uganda and South Africa, infected with non-B HIV subtypes and randomized to receive ART for 48 weeks (ART48) or no therapy. (The SPARTAC trial only recruited female participants in these countries as recruitment was linked to a vaginal microbicide study.) To qualify for this analysis of treatment interruption, participants had to have either received no ART, or to have received between 45 and 50 weeks of ART and to have been fully suppressed ( $\mathrm{pVL}<400$ copies $/ \mathrm{ml}$ ) at treatment interruption. Of the 82 African participants in SPARTAC who were eligible for this substudy and had samples available, 38 were randomized to 'deferred ART' and 44 to the ART48 arm. Of the latter, only 22 contributed to the analysis at the point of treatment interruption (S1 Fig, http://links.lww.com/QAD/B378).

The data from the African participants are compared with data from subtype B-infected participants recruited in the UK, Italy, Ireland, Australia and Brazil (subsequently referred to as the 'non-African cohort') which is described in detail elsewhere [14], and comprised 103 participants, all male and predominantly from the UK (66.0\%). The same criteria for treatment duration and undetectable $\mathrm{pVL}$ as in the African cohort were used for the non-African cohort. Fifty-two non-African participants had been randomized to receive 48 weeks of ART and 51 to no immediate treatment. Forty-four samples were available for analyses at treatment interruption after 48 weeks of ART (Fig S1, http://links.lww.com/QAD/ B378).

Characteristics of participants at randomization and treatment interruption, are shown in Table 1. Due to sample availability, not all assays were performed in all participants at all time-points.

\section{Measurement of HIV DNA}

Thawed peripheral blood mononuclear cell (PBMC) samples were enriched for $\mathrm{CD}^{+} \mathrm{T}$ cells by negative selection (DynabeadsUntouched Human $\mathrm{CD} 4^{+} \mathrm{T}$ cells; Invitrogen, Waltham, Massachusetts, USA) and $\mathrm{CD} 4^{+} \mathrm{T}-$ cell DNA extracted (QIAamp DNA Blood Mini Kit; Qiagen, Hilden, Germany). Cell copy number and total HIV DNA were quantified in triplicate using albumin and HIV qPCR assays [27]. The quantification of subtype C HIV DNA was validated comparing results from MJ4 
Table 1. Participant characteristics for African and non-African participants.

\begin{tabular}{|c|c|c|c|c|}
\hline & \multicolumn{2}{|c|}{ Baseline } & \multicolumn{2}{|c|}{ ART interruption } \\
\hline & Non-African $(n=103)$ & African $(n=82)$ & Non-African $(n=44)$ & African $(n=22)$ \\
\hline Age (years) & 35.0 [30.0-42.5] & $25.0[21.0-31.8]$ & 36.0 [31.3-46.5] & $26.0[21.3-34.0]$ \\
\hline Number of male: female & $103: 0$ & $0: 82$ & $44: 0$ & $0: 22$ \\
\hline \multicolumn{5}{|l|}{ Country } \\
\hline UK & $68(66.0 \%)$ & 0 & $27[61.4 \%]$ & 0 \\
\hline Uganda & 0 & $8(9.8 \%)$ & 0 & $2[9.1 \%]$ \\
\hline South Africa & 0 & $74(90.2 \%)$ & 0 & $20[90.9 \%]$ \\
\hline Other & $35(34.0 \%)^{\mathrm{a}}$ & 0 & $17[38.6 \%]$ & 0 \\
\hline \multicolumn{5}{|l|}{ HIV-1 clade } \\
\hline $\mathrm{A} 1$ & 0 & $2(2.4 \%)$ & 0 & $1(4.5 \%)$ \\
\hline B & $103(100 \%)$ & 0 & $44(100 \%)$ & 0 \\
\hline C & 0 & $51(62.2 \%)$ & 0 & $19(86.5 \%)$ \\
\hline $\mathrm{D}$ & 0 & $3(3.7 \%)$ & 0 & $1(4.5 \%)$ \\
\hline Unknown & 0 & $26(31.7 \%)$ & 0 & $1(4.5 \%)$ \\
\hline $\begin{array}{l}\text { Time from seroconversion to } \\
\text { randomization (weeks) }\end{array}$ & $10.6[7.1-13.6]$ & 13.6 [10.9-16.9] & $10.9[7.3-13.2]$ & $15.5[13.2-17.7]$ \\
\hline Plasma viral load ( $\log _{10}$ copies $\left./ \mathrm{ml}\right)$ & $4.72[4.06-5.27]$ & $4.16[3.37-4.82]$ & $<400$ & $<400$ \\
\hline $\mathrm{CD}^{+}{ }^{-}$-cell count $($cells/ $\mu \mathrm{l})$ & 560 [410-715] & 611 [483-759] & 767 [657-989] & 869 [796-1055] \\
\hline $\begin{array}{l}\text { Total HIV DNA ( } \log _{10} \text { copies/ } \\
\text { million CD4 }{ }^{+} \text {T cells) }\end{array}$ & $3.89[3.46-4.27]$ & $3.82[3.44-4.04]$ & $3.24[2.89-3.44]$ & $3.18[3.06-3.45]$ \\
\hline $\begin{array}{l}\text { Integrated HIV DNA (log }{ }_{10} \text { copies/ } \\
\text { million CD4 }{ }^{+} \mathrm{T} \text { cells) }\end{array}$ & $3.61[3.32-3.80]$ & $3.07[2.81-3.33]$ & $2.99[2.71-3.26]$ & $2.85[2.59-3.22]$ \\
\hline $\begin{array}{l}\text { Time from randomization to last } \\
\text { plasma viral load measurement } \\
\text { (months) }\end{array}$ & $50.2[43.7-56.7]$ & $48.6[43.4-52.6]$ & 53.6 [48.2-61.6] & 50.2 [43.9-54.9] \\
\hline
\end{tabular}

Data are presented as values for categorical data or medians and interquartile ranges [Q1-Q3] in brackets for continuous variables.

${ }^{a}$ Fourteen from Australia, 12 from Italy, eight from Brazil and one from Ireland.

and NL4-3 plasmids, containing subtype C and B HIV DNA sequences, respectively. Integrated HIV DNA was measured by modified [14] Alu-gag nested qPCR [28]. We measured total HIV DNA in African participants at both time-points ( $n=82$ and 22 at baseline and treatment interruption, respectively) and integrated HIV DNA according to sample availability $(n=54$ and 22 at baseline and treatment interruption, respectively). HIV DNA data from the non-African participants were available from a previously published study [14].

\section{Flow cytometry}

Cell surface staining was performed on thawed PBMCs from participants at baseline and treatment interruption according to sample availability $(n=70 / 82$ and $18 / 22$, respectively). PBMCs from 10 healthy Africans were simultaneously run as controls. Two different panels of antibodies were used to explore markers of immune activation (CD25, CD69, CD38, HLA-DR) and exhaustion (Lag-3, Tim-3, PD-1) (see Supplementary Material for full details, http://links.lww.com/QAD/B378).

\section{Unspliced cell-associated HIV-1 RNA transcript quantitation}

RNA was isolated from PBMCs of all 22 participants at treatment interruption, using the AllPrep DNA/RNA Mini kit (Qiagen) with the addition of an on-column double DNase digestion. The RNA assay was a modified version of those previously described [29,30]. Briefly, complementary DNA was subjected to two rounds of
PCR using seminested primers. The HIV standard was generated in-vitro transcribing the plasmid Sp5-NL4.3 (generously provided by the lab of D. Purcell) using the RiboMax Large Scale SP6 RNA production System (Promega, Madison, Wisconsin, USA). HIV RNA standards were diluted in $10 \mathrm{ng} / \mu \mathrm{l}$ uninfected PBMC RNA. HIV measurements were normalized to input cellular RNA using the 18S gene with the Amplifluor Human/Mouse 18S rRNA Primer Set (FAM labelled; Millipore, Burlington, Massachusetts, USA). The standards for this assay were derived from an HIV subtype B plasmid. Oligo dT and random hexamers were used for reverse transcription to remove any potential for subtypespecific bias. The HIV-specific component of the reaction was the same as for the HIV DNA assay, validated for subtype $\mathrm{C}$ amplification as above.

\section{HLA class I phenotyping}

HLA class I type was determined to the oligo-allelic level using Dynal RELITM Reverse Sequence-Specific Oligonucleotide kits for the HLA-A, B and C loci (Dynal Biotech, Thermo FIsher, Brown Deer, Wisconsin, USA). To obtain four-digit typing, Dynal Biotech Sequence-Specific priming kits were used, in conjunction with the Sequence-Specific Oligonucleotide type.

\section{$\mathrm{CD8}^{+}$T-cell ELISpot assays}

HIV Gag-specific CD $8^{+}$T-cell responses were measured by IFN- $\gamma$ ELISpot assays to overlapping peptides using methods described elsewhere [31,32]. 


\section{Statistical analysis}

Comparison of continuous variables was performed with Mann-Whitney, or Wilcoxon tests for matched samples. Spearman correlations were used to analyse HIV DNA, $\mathrm{pVL}$ and $\mathrm{CD}^{+}$cell count associations. Correlations between virological, immunological and reservoir markers were displayed through correlograms ( $R$ package 'correlogram'), the order of biomarkers determined by hierarchical clustering. Associations between HIV DNA and immunological markers in the African participants were explored further with regression models. We used backward selection (exit criteria $P<0.1$ ) on variables presenting with $P<0.2$ in simple linear regression models to identify those to include in multivariable regression models. Integrated HIV DNA was not considered in these analyses because of the strong association with total HIV DNA. Association between baseline or treatment interruption markers and SPARTAC endpoints was assessed using Cox proportional hazards models. Kaplan-Meier survival analysis and log-rank tests were used to compare remission periods after treatment interruption. All plots and statistics were made on RStudio version 0.98.1103; R Studio, Boston, Massachusetts, USA).

\section{Results}

\section{Characteristics of African participants}

Characteristics of all participants at randomization and treatment interruption, are shown in Table 1. For the African cohort, 82 female participants recruited from Uganda $(n=8)$ and South-Africa $(n=74)$ had samples available at pretherapy baseline. All were originally randomized within a median [interquartile range, IQR] of 13.6 [10.9-16.9] weeks from the estimated date of seroconversion. All infections were with non-B HIV subtypes, mainly C (62.2\%). Median [IQR] age was 25.0 [21.0-31.8] years. Heterosexual intercourse was the main mode of HIV transmission. We studied participants who had been randomly assigned to receive either deferred ART $(n=38)$ or 48 weeks of ART ('ART48' group; $n=44$ ). Only 22 of the 44 ART48 participants in this subanalysis had both received 48 full weeks of ART and suppressed viral replication ( $\mathrm{pVL}<400$ copies $/ \mathrm{ml}$ ) at the time of treatment interruption (Table 1). As a result, even though baseline pretherapy data are included for the 44 treated participants, only data for 22 are available for analysis at treatment interruption. (Of the 22 participants excluded, 13 received $<46$ weeks of ART and nine had a $\mathrm{pVL}>400$ copies $/ \mathrm{ml}$ at treatment interruption.)

Demographics of the African and non-African cohorts at randomization and treatment interruption were similar except that time from the estimated date of seroconversion to randomization was significantly longer in the African than non-African cohort with median [IQR] values of $13.6[10.9-16.9]$ and 10.6 [7.1-13.6] weeks, respectively $(P<0.001$; Mann-Whitney).

\section{Lower plasma viral load and HIV DNA at baseline in African compared with non-African participants}

We compared the African cohort with participants from Europe, Australia and Brazil (Table 1; 'non-African cohort'), reported previously [14]. At pretherapy baseline, the median [IQR] pVL in the African cohort (4.16 [3.37-4.82] $\log _{10}$ copies/ml) was significantly lower than the non-African cohort (4.72 [4.06-5.27] $\log _{10}$ copies/ ml) $(P<0.001$; Mann-Whitney) (Table 1; Fig. 1a). $\mathrm{CD}^{+}{ }^{+}$T-cell counts were not significantly different between the African and non-African cohorts at either baseline or treatment interruption (Table 1; Fig. 1b). Mean CD4 ${ }^{+}$T-cell counts improved over the 48 weeks of ART for both cohorts, although this was only statistically significant for the African participants $(P<0.001$; Wilcoxon signed-rank test) (Fig. 1b, Fig S2A, http:// links.lww.com/QAD/B378). At baseline, integrated (but not total) HIV DNA was lower in Africans compared with non-Africans $(P<0.001$; Mann-Whitney), while no difference in HIV DNA level was observed at treatment interruption (Table 1; Fig. 1c and d). There was a significant decrease in both forms of HIV DNA in African and non-African participants on ART $(P<0.001$ for both; Wilcoxon signed-rank test) (Fig. 1c and d, Fig S2B, http://links.lww.com/QAD/B378), the magnitude of the change in total and integrated HIV DNA being greater in the non-African cohort $(P=0.013$ and 0.012 , respectively; Wilcoxon signed-rank test).

\section{Correlates of HIV reservoir size in African participants}

In African participants, total and integrated HIV DNA were closely correlated at randomization and treatment interruption $(P<0.001$; rho $=0.706$ and 0.843 , respectively; Spearman) (Fig S3A, B, http://links.lww.com/ $\mathrm{QAD} / \mathrm{B} 378)$, and were inversely associated with $\mathrm{CD} 4^{+}$ T-cell count at baseline $(P<0.001$, rho $=-0.560$ for both forms; Spearman) (Fig. 1e) and treatment interruption $(P=0.049$, rho $=-0.425$ for both forms; Spearman $)$ (Fig S3C, http://links.lww.com/QAD/B378). HIV DNA was positively correlated with baseline pVL $(P<0.001 ; R=0.47$ and 0.60 for total and integrated HIV DNA, respectively; Spearman) (Fig. 1f).

We wished to determine how these markers associated more broadly with other virological, immunological and reservoir markers, and employed principle component analysis with correlograms [33] to represent the clustering and strength of individual associations (Fig. 2). At baseline and treatment interruption, PD-1, HLA-DR and Lag-3 on both $\mathrm{CD}^{+}$and $\mathrm{CD}^{+}{ }^{+} \mathrm{T}$ cells clustered together with similar positive correlations (Fig. 2a and b). At baseline, there was also clustering with $\mathrm{CD} 38^{+}$on $\mathrm{CD}^{+} \mathrm{T}$ cells and Tim -3 on $\mathrm{CD}^{+}{ }^{+} \mathrm{T}$ cells. Association of these markers 
(a)
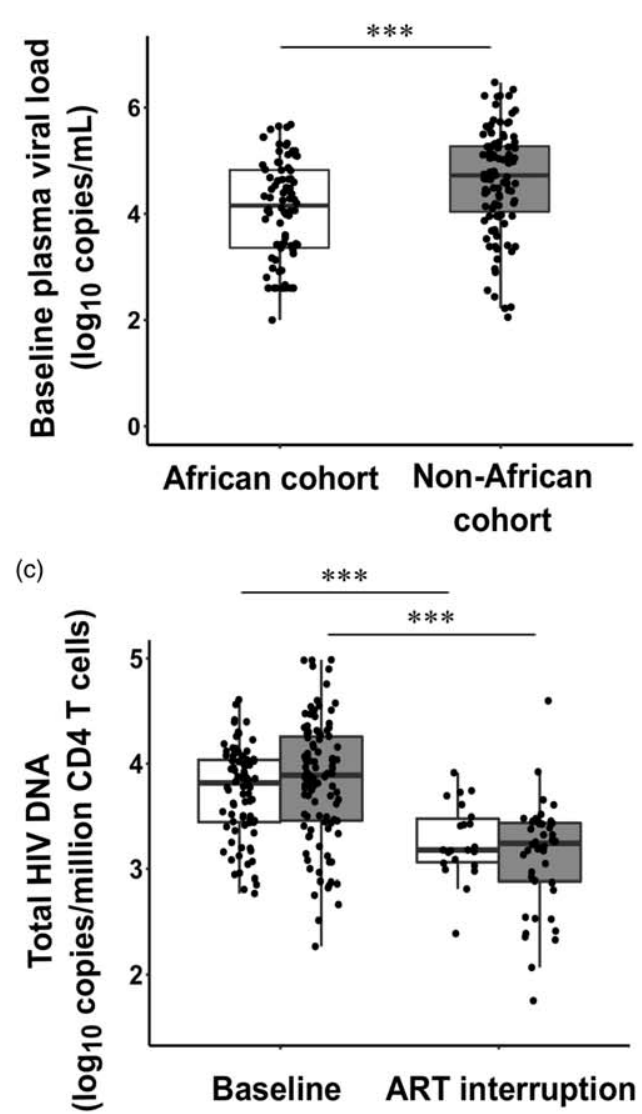

(e)

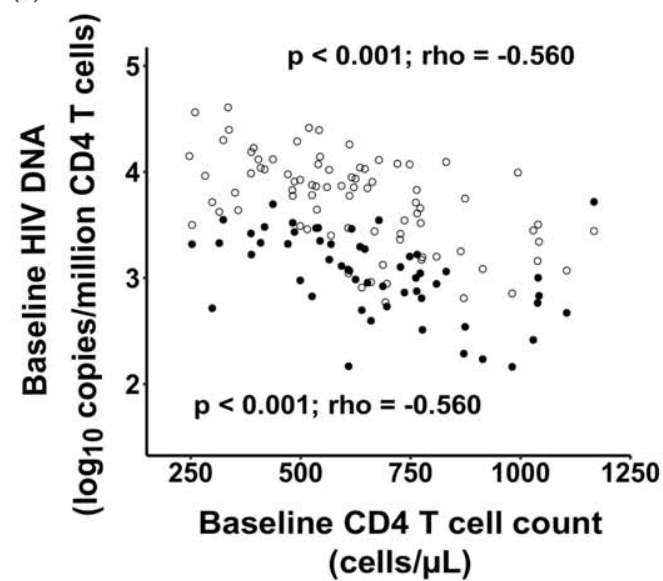

(b)

African cohort

Non-African cohort

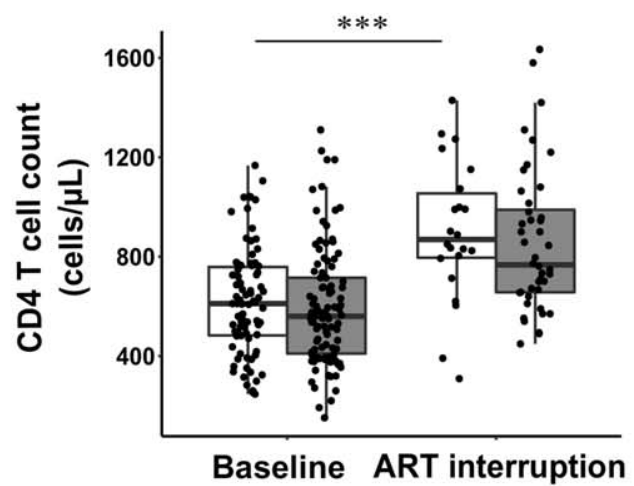

(d)

(f)
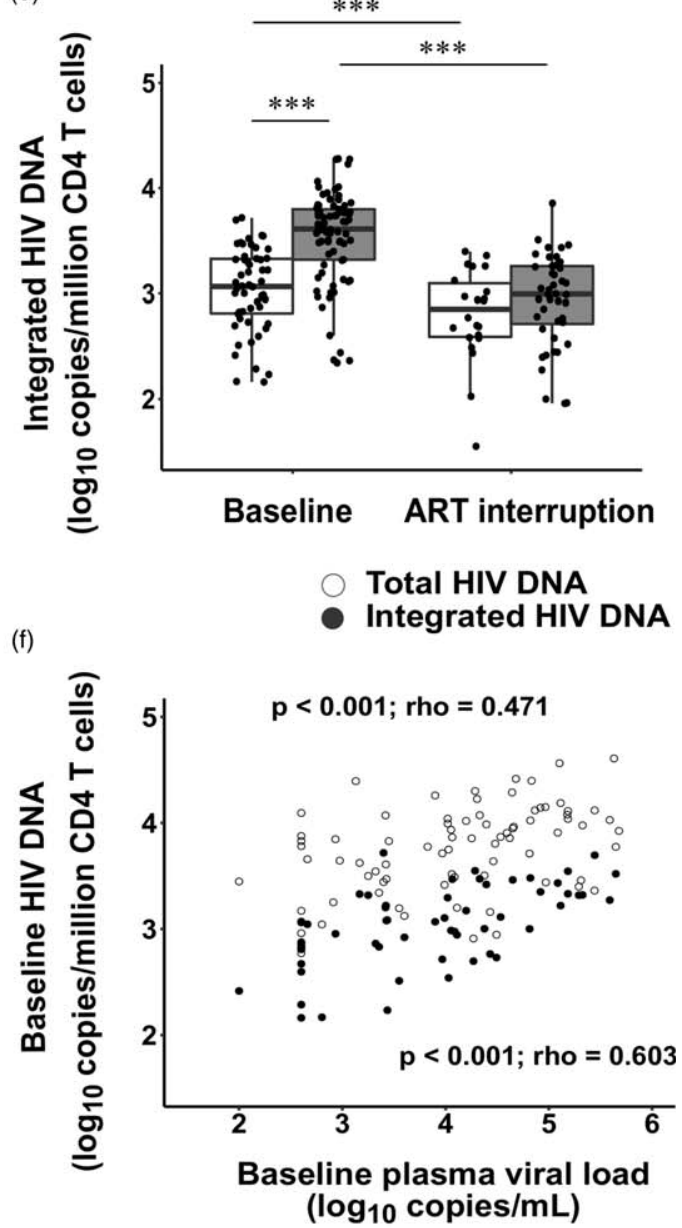

Fig. 1. Baseline and treatment interruption characteristics of reservoir-associated markers in the African and non-African cohorts. Reservoir-associated markers were compared between the African cohort (open boxes) and non-African cohort (grey boxes) at baseline ( $n=82$ and 103, respectively) and antiretroviral therapy (ART) interruption ( $n=22$ and 44 , respectively). Plasma viral load (a), CD4 ${ }^{+}$T-cell count (b), total HIV DNA (c) and integrated HIV DNA (d) were studied. Correlations between HIV DNA and $\mathrm{CD}^{+}{ }^{+}$-cell count (e) and plasma viral load ( $\mathrm{f}$ ) were considered at baseline (open and black dots for total and integrated HIV DNA, respectively). Integrated HIV DNA data at baseline were available for only 54 and 77 participants from the African and nonAfrican cohorts, respectively. Comparisons were performed using nonparametric Mann-Whitney tests. When studying the evolution after 48 weeks of ART, only data from participants with results at both time points were analysed and compared by paired Wilcoxon test. Correlations were tested using Spearman correlations. $* * * P<0.001$. 
(a)

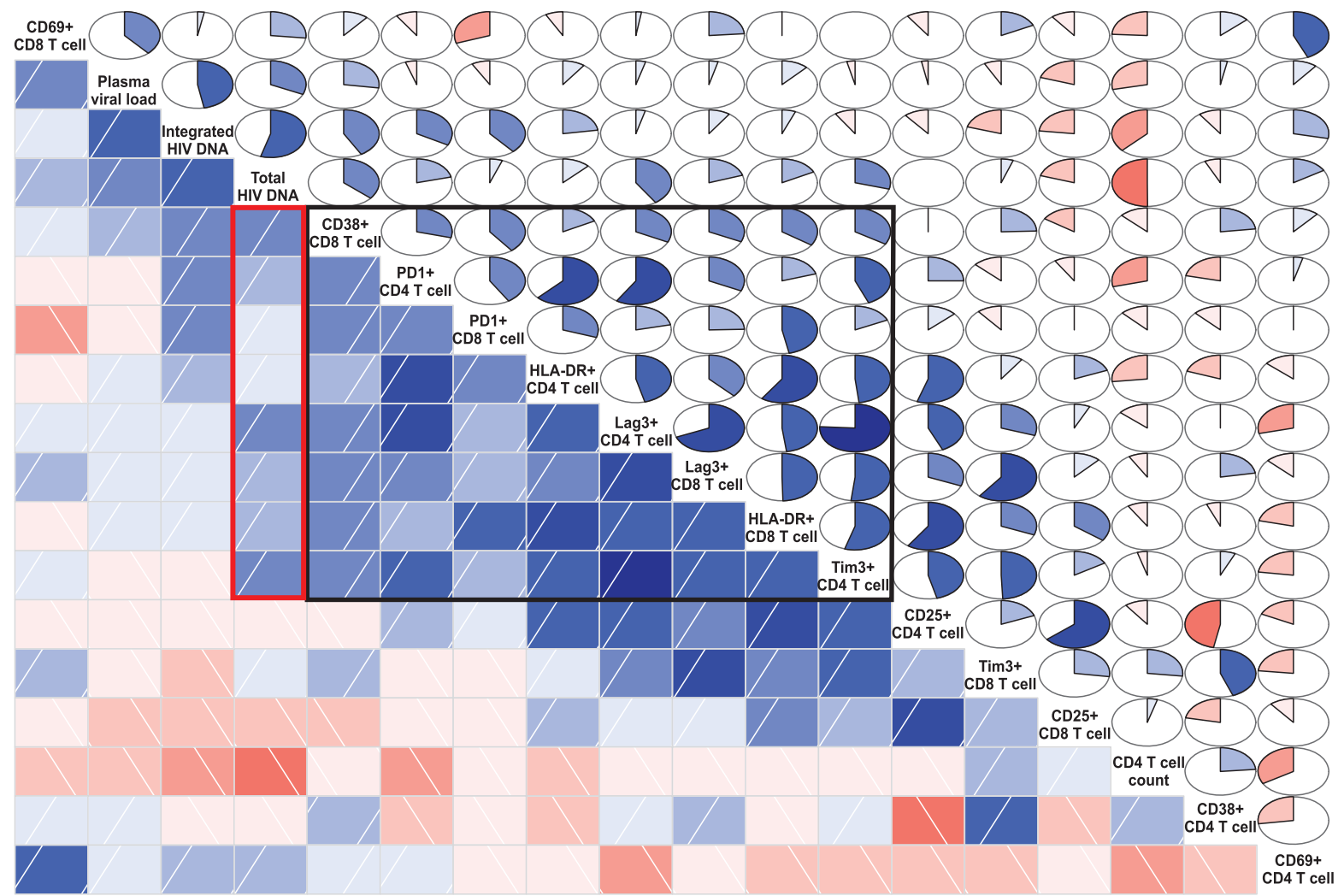

(b)

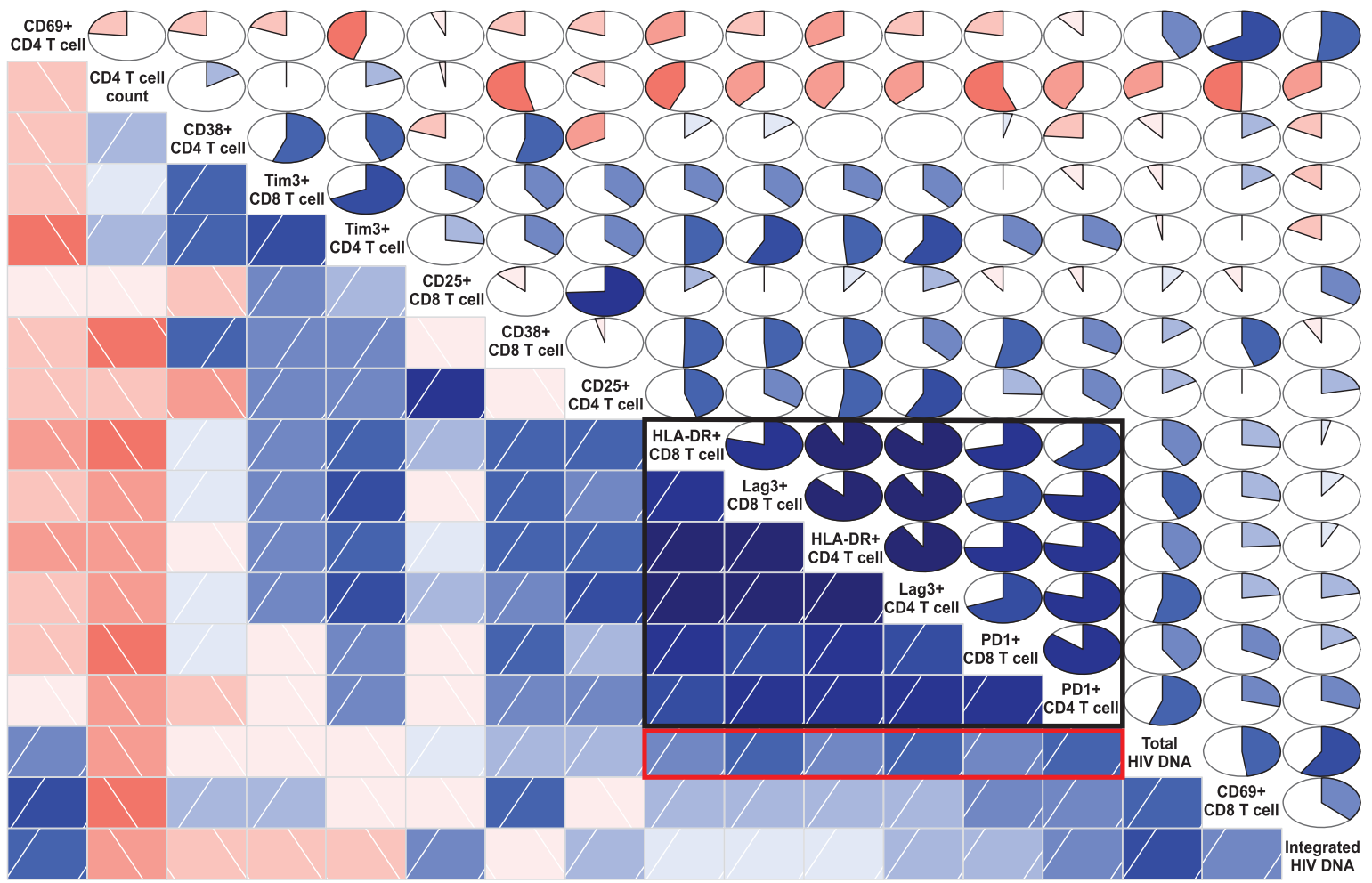

Fig. 2. Association between reservoir-associated and immunological markers in the African cohort. Correlograms of baseline $(n=70)$ (a) and antiretroviral therapy (ART) interruption variables $(n=18)(\mathrm{b})$. Strength of associations is illustrated by pie charts and heat maps, red showing negative correlation and blue a positive correlation between parameters. Intensity of the colour and size of the pie is linked to the strength of the association. Variables were arranged by hierarchical clustering, in PC2/PC1 order. Immunological variables strongly associated together are indicated in the black box, and in red boxes if strongly associated with reservoir-associated markers. 
with HIV DNA was also evident at pretherapy baseline (Fig. 2a, red box), but was stronger at treatment interruption (Fig. 2b, red box).

Associations between HIV DNA and immunological markers in the African participants were explored further with regression models. In the multivariable analysis, Lag3 expression on $\mathrm{CD}^{+}{ }^{+} \mathrm{T}$ cells, $\mathrm{CD} 4^{+} \mathrm{T}$-cell count and pVL were independently associated with HIV DNA at baseline (Table S1, http://links.lww.com/QAD/B378). At treatment interruption, expression of Lag-3 and $\mathrm{CD} 69^{+}$on $\mathrm{CD}^{+}{ }^{+} \mathrm{T}$ cells were associated with HIV DNA (Table S1, http://links.lww.com/QAD/B378).

\section{HIV DNA and clinical progression}

The primary end-point in the SPARTAC trial was a composite of a CD4 ${ }^{+}$T-cell count decline to less than 350 cells/ $\mu$ l or initiation of long-term ART, and was used in this analysis as a correlate of disease progression [13]. At baseline $(n=82)$, univariable Cox analyses identified HIV DNA (total and integrated), pVL and $\mathrm{CD} 4^{+} \mathrm{T}$-cell count to be predictive of clinical progression (when adjusting for therapy), although only $\mathrm{CD} 4^{+} \mathrm{T}$-cell count was independently associated with the primary endpoint in multivariable analyses (HR 0.47 per 100 cells $/ \mu$ increase [CI $0.28-0.66$ ] $P<0.001$ ) (S2 Table, http://links.lww.com/QAD/B378). For T-cell activation and exhaustion markers (when adjusted for ART duration), proportions of $\mathrm{CD} 38^{+}$and $\mathrm{CD} 69^{+}$ $\mathrm{CD}^{+}{ }^{+} \mathrm{T}$ cells $(P=0.008$, HR 0.96 [0.93-0.98] and $P=0.011$, HR 1.47 [1.09-1.97], respectively), and Tim$3+\mathrm{CD}^{+} \mathrm{T}$ cells $(P=0.045$, HR $0.91[0.83-0.999])$ were significantly associated with progression, although not in multivariable models (S3 Table, http://links.lww.com/QAD/B378). When measured at ART interruption, neither total nor integrated HIV DNA predicted progression (despite suggestive hazard ratios (HR [95\% CI] 2.58 [0.19-34.69] and 10.2 [0.55-190.5], respectively) (S4 Table, http://links.lww.com/QAD/B378).

\section{HIV DNA and time to viral rebound in African women}

Next, we turned to analyses of time to viral rebound after treatment interruption, utilizing data from the 22 African participants who received 48 weeks of ART and had undetectable $\mathrm{pVL}$ at treatment interruption. At baseline, total HIV DNA (HR 4.33 per $\log _{10}$ increase [CI 1.1216.84]; $P=0.034$ ) and $\mathrm{pVL}$ (HR 1.93 per $\log _{10}$ increase [CI 1.17-3.17]; $P=0.010$ ) predicted time to $\mathrm{pVL}$ rebound in univariable models. When adjusted for pVL, CD4 ${ }^{+}$T-cell count or integrated HIV DNA, the association with pretherapy total HIV DNA was no longer significant. When measured at treatment interruption, neither total (HR 3.48 per $\log _{10}$ increase [CI $0.78-15.49] ; P=0.102)$ nor integrated HIV DNA (HR 2.65 per $\log _{10}$ increase [CI $0.79-8.9$ ]; $P=0.114$ ) were associated with time to viral rebound, despite supportive hazard ratios. No activation or exhaustion marker was predictive of time to viral rebound at any time point ( 55 Table, http://links.lww.com/QAD/B378).

\section{Longer posttreatment remission in African women compared with non-African men}

We next compared time to $\mathrm{pVL}$ rebound after stopping ART in the African and non-African participants. Kaplan-Meier survival analysis revealed a significant delay in time to viral rebound in African compared to non-African participants $(P<0.001 ; \quad \log$-rank test $)$ (Fig. 3a), which was supported in multivariable Cox models adjusting for HIV DNA and $\mathrm{CD}^{+}{ }^{+}$T-cell count (S6 Table, http://links.lww.com/QAD/B378). All nonAfrican participants eventually experienced viral rebound after treatment interruption (Fig. 3a); however, five of the 22 African women controlled viraemia below 400 copies/ $\mathrm{ml}$ after treatment interruption until the end of follow-up (median [IQR] 4.48 years [3.99-4.65]). In subsequent analyses, we refer to these five individuals from the African cohort as 'posttreatment controllers' (PTC), as opposed to the 17 African 'noncontrollers' (NC).

\section{Comparison of posttreatment controllers and noncontrollers}

Time from seroconversion to ART initiation was similar in the African PTC (median [IQR] 17.6 [17.1-17.8]) and 'noncontrollers' groups (14.3 [13.0-17.6] weeks) $(P=0.147$; Mann-Whitney). At baseline, PTC had significantly lower $\mathrm{pVL}(P=0.041$; Mann-Whitney) and higher $\mathrm{CD}^{+}{ }^{+} \mathrm{T}$-cell counts $(P=0.011$; Mann-Whitney) than 'noncontrollers'. The median $\mathrm{CD} 4{ }^{+}$T-cell count at treatment interruption was also higher in PTC $(P=0.006$; Mann-Whitney) (Fig. $3 \mathrm{~b}$ and c). A trend towards lower levels of total and integrated HIV DNA $(P=0.058$ and $P=0.085$, respectively; Mann-Whitney) in PTC was evident at baseline (Fig. 3d and e). At ART interruption, no difference in total or integrated HIV DNA was found between groups (Fig. $3 \mathrm{~d}$ and e); however, there was a trend for PTC to have lower levels of cell-associated RNA, with median [IQR] values of -0.36 [ -0.38 to 1.38$]$ vs. 1.51 [0.90 to 2.10$] \log _{10}$ copies/ million copies of $18 \mathrm{~S}$ RNA, respectively $(P=0.153)$ (Fig. 3f). The only statistically significant difference between PTC and 'noncontrollers' in regards to T-cell activation and exhaustion (Fig. $3 \mathrm{~g}-\mathrm{j}$ ) in univariate analysis, was a lower proportion of $\mathrm{PD} 1+\mathrm{CD} 8^{+} \mathrm{T}$ cells in PTC at treatment interruption (Fig. 3j), (although this result did not survive Bonferroni correction for multiple comparisons).

\section{Posttreatment controllers maintain stable $\mathrm{CD4}^{+}$ T-cell counts and HIV DNA levels after treatment interruption}

Measures of pVL, CD4 ${ }^{+}$T-cell count and total HIV DNA during follow-up are presented for the five PTCs (Fig. 4). Four PTC had subtype C HIV while the subtype was unknown for the fifth PTC individual, as no sequence could be obtained. Three PTC experienced 


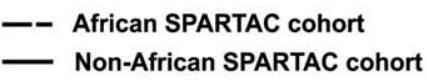

(a)

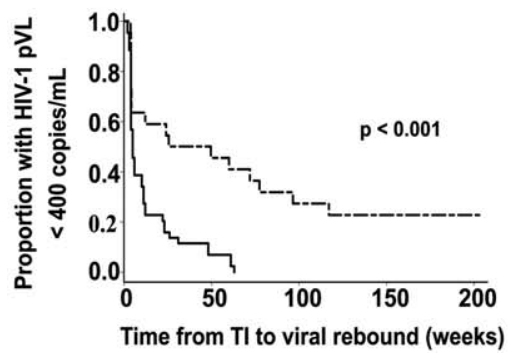

(d)

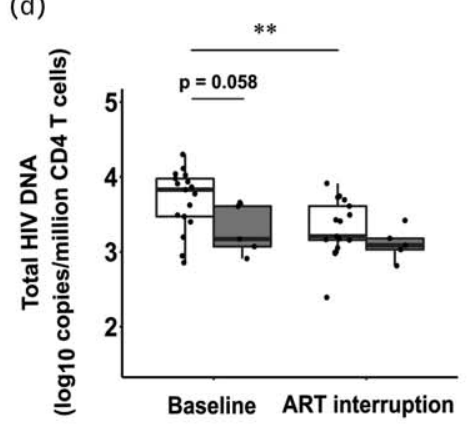

(g)

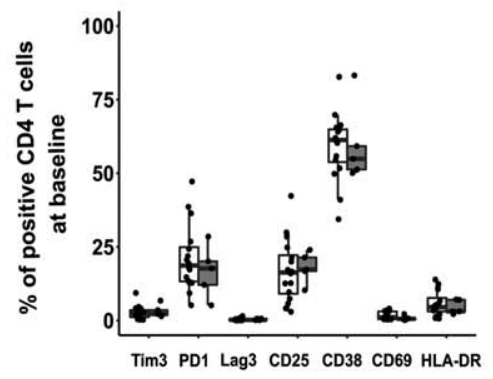

Sustained controllers

Non controllers

(b)

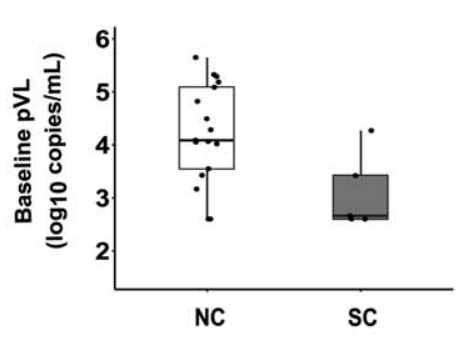

(e)

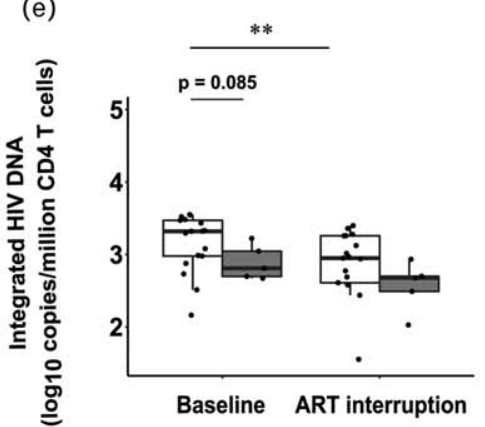

(h)

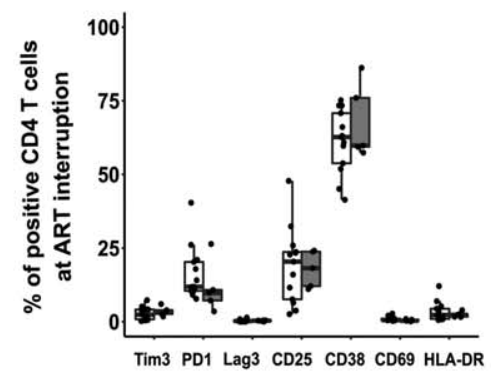

(j)

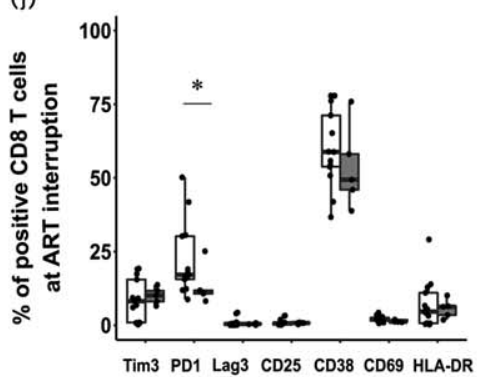

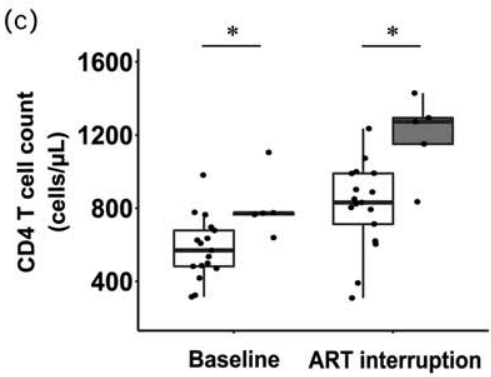

(f)

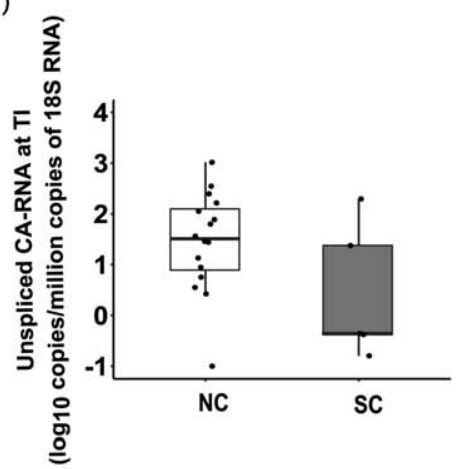

(i)

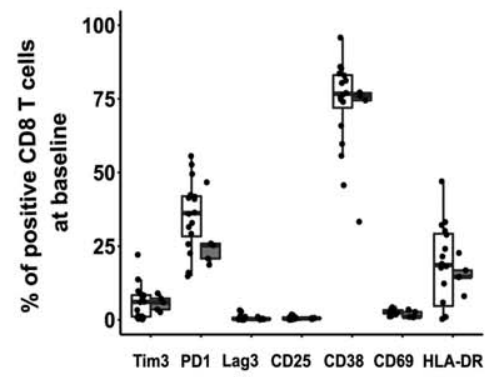

Fig. 3. Determinants of time to virological failure and sustained control in the African cohort. (a) Survival analyses of time to viral rebound (weeks) of participants undertaking treatment interruption after 48 weeks of antiretroviral therapy (ART) in the African cohort (dashed line, $n=22$ ) and the non-African cohort (solid line, $n=44$ ). Significance was determined by log-rank test. Reservoirassociated markers were compared between the sustained controllers (grey boxes; $n=5$ ) and the non-controllers (open boxes; $n=17$ ) from the African cohort: plasma viral load (b) was measured at baseline, while CD4 ${ }^{+} \mathrm{T}$-cell count (c), total HIV DNA (d) and integrated HIV DNA (e) were studied at both baseline and treatment interruption; unspliced cell-associated HIV RNA (f) was analysed at treatment interruption. Immunological markers were also compared in the sustained controllers $(n=5)$ and the non-controllers ( $n=16$ at baseline and 13 at treatment interruption). Expression of activation and exhaustion markers was studied on $\mathrm{CD}^{+}$and CD $^{+}$ $\mathrm{T}$ cells at baseline ( $\mathrm{g}$ and $\mathrm{i}$, respectively) and treatment interruption ( $\mathrm{h}$ and $\mathrm{j}$, respectively). Comparisons between the two groups were performed using nonparametric Mann-Whitney test, while comparison between time-points within a same group was done using a paired Wilcoxon test. $* P<0.05, * * P<0.01$. 
(a)

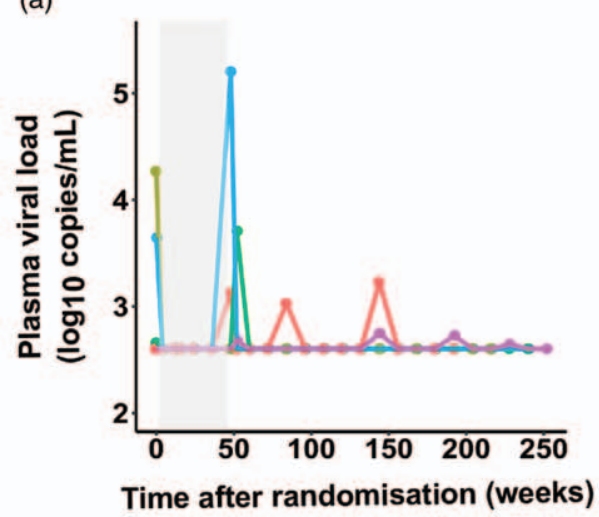

(c)

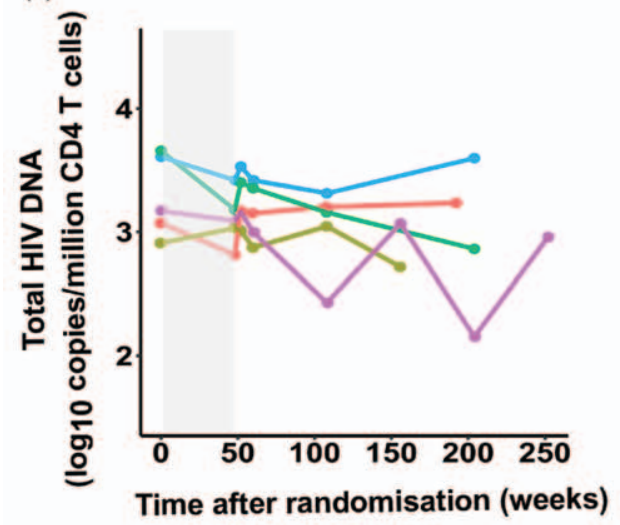

(e)

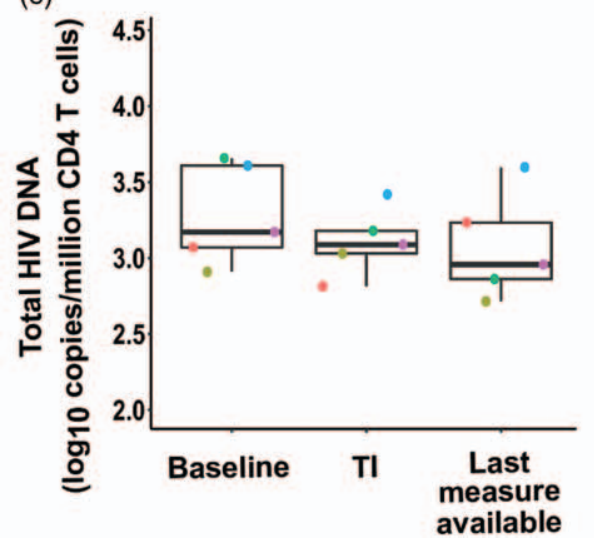

(b)

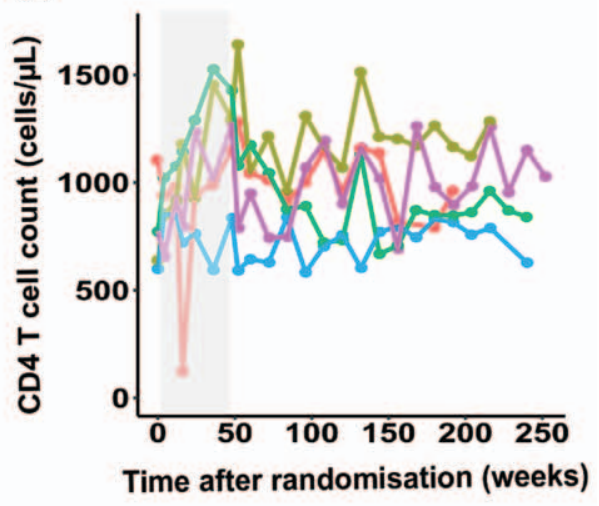

(d)

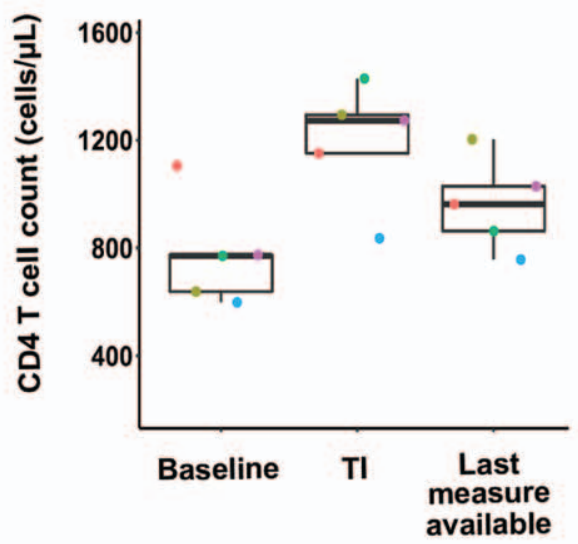

Fig. 4. Individual evolution of reservoir-associated markers in sustained controllers from the African cohort during the followup period of the trial. Plasma viral load (a), CD4 ${ }^{+}$T-cell count (b) and total HIV DNA (c) were measured at different time-point throughout the clinical trial in the five sustained controllers. These individuals underwent 48 weeks of antiretroviral therapy (ART) during primary HIV infection (grey area) then interrupted the treatment. Global evolution of CD4 ${ }^{+} \mathrm{T}_{\text {-cell count }}(\mathrm{d})$ and total HIV DNA (e) in the group of sustained controllers was studied at pretherapy baseline, ART interruption and last time point with samples available for total HIV DNA measurement (median of 204 weeks, min 156-max 252 weeks).

pVL blips after treatment interruption (maximum blips: 1690, 5110, 560 copies $/ \mathrm{ml}$ ), whereas two maintained undetectable viraemia throughout follow-up (Fig. 4a). Two of the PTC had undetectable pVL at randomization, prior to starting ART, and one just above the detection limit, at 459 copies/ml (Fig. 4a). $\mathrm{CD}^{+}{ }^{+}$T-cell counts increased during the 48 weeks of ART (median [IQR] 772 [639-775] cells/ $\mu \mathrm{l}$ at baseline vs. 1273 [1151-1294] cells $/ \mu l$ at treatment interruption) and then decreased after treatment interruption (although not significantly) when measured at the last documented trial time-point

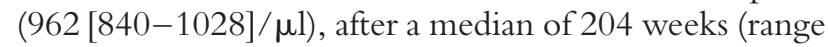


156-252) (Fig. 4b and d). Total HIV DNA levels remained stable (median [IQR] values of 3.17 [3.073.61] at baseline, $3.09[3.03-3.18]$ at treatment interruption and 2.96 [2.86-3.23] copies/million $\mathrm{CD}^{+}{ }^{+} \mathrm{T}$ cells at end of follow-up (Fig. $4 \mathrm{c}$ and e)).

We looked for associations between PTC and HLA Class I - the key genetic association with HIV progression [34]. Two participants with undetectable pVL prior to ART had the protective HLA-B*81:01 and made dominant responses to the HIV Gag TPQDLNTML epitope which is associated with control $[35,36]$; one of these also had B*35:01 (Table S7, http://links.lww.com/QAD/B378). In comparison, among 17 'noncontrollers' participants, six carried the disease susceptible allele HLA-B*58:02 and four had protective alleles HLA-B*81:01 or HLA$B * 57: 03$.

\section{Discussion}

The SPARTAC trial offered the unique opportunity to study the outcome of a randomized treatment interruption in African women with PHI infected with non-B HIV subtypes. To our knowledge, our study is the first to both characterize the impact of treatment interruption in African participants treated at PHI and also to compare HIV reservoir dynamics in African and non-African participants within the same RCT. Whereas interrupting ART is not recommended in current guidelines, there is increasing interest in the value of an intensively monitored treatment interruption in studies testing for virological remission or the impact of a novel intervention on the reservoir or host immunity. However, stopping ART should only be done in the context of a clinical study with a clearly defined question and under close supervision.

Our study has important confounding factors, which have been discussed previously [37], but which do not negate the difference in outcomes in the two study groups. First, we describe our cohorts as 'African' and 'non-African', although we could justifiably have described them as female and male. It has been previously documented that HIV-uninfected and infected women have higher $\mathrm{CD}^{+}{ }^{+}$T-cell counts than men [38-42]. In untreated individuals, HIV-infected women have lower $\mathrm{pVL}$ compared to men, including when adjusting for confounding factors [39,43-45]. HIV subtypes may also have differential characteristics, such as replication fitness and biology of transmission, which could impact disease progression and response to therapy $[21,22,24-26]$. However, to date this has not been definitively proven in clinical cohorts due to confounders such as sex, ethnicity and heterogeneity in time intervals since seroconversion [46-48]. Gender-matched studies will be necessary to determine whether sex or viral subtype is the major driver of our results as our non-African cohort were all male. However, the practicalities of a sexmatched study from PHI in Africa are not straightforward and a similar dataset may be hard to reproduce.

Pretherapy African participants had lower integrated HIV DNA and $\mathrm{pVL}$ than non-African participants consistent with the sex difference and other studies [49]. Correlations between pVL, CD4 ${ }^{+}$T-cell counts and HIV DNA have been previously described in African cohorts [20,46,50,51], but without associated virological, immunological and clinical outcomes. HIV DNA levels pre-ART in the African participants correlated with $\mathrm{pVL}$ and several T-cell activation and exhaustion markers (e.g. CD38, Lag-3, Tim-3). After 48 weeks of ART, Lag-3, CD69 and PD-1 expression on $\mathrm{CD} 4^{+} \mathrm{T}$ cells correlated with HIV DNA. That a number of these associations existed independently supports previous data showing that immune activation in HIV-infected African individuals correlates with $\mathrm{pVL}$ and inversely with $\mathrm{CD} 4^{+}$cell count [52].

In European cohorts, HIV DNA [14,53-55] and immune activation and exhaustion [1,56-59] have been reported as independent predictors of clinical progression. Different rates of disease progression have been associated with non-B subtypes of HIV $[39,47]$ and in untreated African individuals [60,61]. Consistent with these findings, we found baseline total and integrated HIV DNA, as well as several T-cell activation and exhaustion markers, to be predictive of clinical progression in the African group.

Our study is one of the first to explore biomarkers of progression in Africans after ART treatment interruption. Although no marker measured at treatment interruption was significantly associated with clinical outcome despite high hazard ratios, this may be related to small sample size. This might explain the disparity with the findings from the larger non-African SPARTAC cohort where HIV DNA (both total and integrated) predicted the primary end-point when measured at treatment interruption [14].

Even considering the variation between $\mathrm{pVL}$ and integrated (but not total) HIV DNA in the two cohorts at baseline, the extent of the difference in times to $\mathrm{pVL}$ rebound in the African and non-African cohort was unexpected. The five African individuals who did not experience $\mathrm{pVL}$ rebound during the course of follow up had lower $\mathrm{pVL}$ and higher $\mathrm{CD} 4^{+}$cell counts than African noncontrollers and lower HIV DNA levels prior to ART initiation. They also maintained higher $\mathrm{CD}^{+}$cell counts at treatment interruption, and while no difference was found in HIV DNA levels, PTC had lower cell-associated RNA levels. Immune activation was similar in both groups, although there were fewer exhausted $\mathrm{CD}^{+} \mathrm{T}$ cells in PTC based on a lower proportion of PD1+ cells. Three of the African PTC, therefore, exhibited characteristics more closely associated with T-cell-mediated immune 
control as described in elite controllers, which again may also be impacted by the gender difference. This raises the important issue of discriminating posttreatment control from treated 'controllers' in these analyses, and the key value of pretherapy measurements.

The best characterized cohort of posttreatment controllers is the VISCONTI study [6]. The African PTC in our study had lower $\mathrm{pVL}$ and higher $\mathrm{CD}^{+}$cell counts than VISCONTI PTC at baseline. Interestingly, African controllers had similar baseline levels of $\mathrm{pVL}$ and $\mathrm{CD} 4^{+}$ cell counts as spontaneous HIV controllers (HIC) described by Saez-Cirion et al. [6] Occasional blips were recorded for some individuals in both VISCONTI and our African controllers, and HIV DNA remained stable both on and off treatment. In VISCONTI, no overrepresentation of protective HLA class I alleles was described, whereas there was a high prevalence of risk alleles. We found the opposite picture in the African controllers, with none having disease susceptible alleles, and two making strong immune responses restricted by B*8101, a known protective allele. HIV-specific T-cell immunity and subsequent escape [59] are drivers of viraemic control and rebound in untreated individuals, but are less well characterized in the context of posttreatment control. Finally, we showed that African controllers had comparable levels of immune activation to African noncontrollers, whereas PTC in VISCONTI had low levels of T-cell activation $[6,62]$.

SPARTAC provided the unique opportunity to characterize the HIV reservoir in African individuals with PHI, with the additional strength of randomized treatment interruption and natural history arms. Although it is likely that our dataset was underpowered for some of the outcomes, there was strong evidence for better virological control in the African participants after treatment interruption compared to the non-African cohort. However, the sustained control seen in five African women adds to the argument that the mechanisms driving the interaction between posttreatment remission and spontaneous control need further study.

\section{Acknowledgements}

The SPARTAC Trial Investigators: Trial Steering Committee: Independent members - A. Breckenridge (Chair), P. Clayden, C. Conlon, F. Conradie, J. Kaldor*, F. Maggiolo, F. Ssali. Country principal investigators D.A. Cooper, P. Kaleebu, G. Ramjee, M. Schechter, G. Tambussi, J.M. Miro, J. Weber. Trial physician - S. Fidler. Trial statistician - A. Babiker. Data and Safety Monitoring Committee (DSMC) -T. Peto (Chair), A. McLaren (in memoriam), V. Beral, G. Chene, J. Hakim. Coordinating trial centre -Medical Research Council Clinical Trials Unit, London (A. Babiker, K. Porter,
M. Thomason, F. Ewings, M. Gabriel, D. Johnson, K. Thompson, A. Cursley*, K. Donegan*, E. Fossey*, P. Kelleher*, K. Lee*, B. Murphy*, D. Nock*). Central Immunology Laboratories and Repositories -The Peter Medawar Building for Pathogen Research, University of Oxford, UK (R. Phillips, J. Frater, L. Ohm Laursen*, N. Robinson, P. Goulder, H. Brown). Central Virology Laboratories and Repositories - Jefferiss Trust Laboratories, Imperial College, London, UK (M. McClure, D. Bonsall*, O. Erlwein*, A. Helander*, S. Kaye, M. Robinson, L. Cook*, G. Adcock*, P. Ahmed*). Clinical Endpoint Review Committee: N. Paton, S. Fidler. Investigators and Staff at Participating Sites - Australia: St Vincents Hospital, Sydney (A. Kelleher), Northside Clinic, Melbourne (R. Moore), East Sydney Doctors, Sydney (R. McFarlane), Prahran Market Clinic, Melbourne (N. Roth), Taylor Square Private Clinic, Sydney (R. Finlayson), The Centre Clinic, Melbourne (B. Kiem Tee), Sexual Health Centre, Melbourne (T. Read), AIDS Medical Unit, Brisbane (M. Kelly), Burwood Rd Practice, Sydney (N. Doong), Holdsworth House Medical Practice, Sydney (M. Bloch), Aids Research Initiative, Sydney (C. Workman). Coordinating Centre in Australia: Kirby Institute University of New South Wales, Sydney (P. Grey, D.A. Cooper, A. Kelleher, M. Law). Brazil: Projeto Praca Onze, Hospital Escola Sao Francisco de Assis, Universidade federal do Rio de Janeiro, Rio de Janeiro (M. Schechter, P. Gama, M. Mercon*, M. Barbosa de Souza, C. Beppu Yoshida, J.R. Grangeiro da Silva, A. Sampaio Amaral, D. Fernandes de Aguiar, M. de Fatima Melo, R. Quaresma Garrido). Italy: Ospedale San Raffaele, Milan (G. Tambussi, S. Nozza, M. Pogliaghi, S. Chiappetta, L. Della Torre, E. Gasparotto), Ospedale Lazzaro Spallanzani, Roma (G. DOffizi, C. Vlassi, A. Corpolongo). South Africa: Cape Town: Desmond Tutu HIV-1 Centre, Institute of Infectious Diseases, Cape Town (R. Wood, J. Pitt, C. Orrell, F. Cilliers, R. Croxford, K. Middelkoop, L.G. Bekker, C. Heiberg, J. Aploon, N. Killa, E. Fielder, T. Buhler). Johannesburg: The Wits Reproductive Health and HIV-1 Institute, University of Witswatersr and, Hillbrow Health Precinct, Johannesburg (H. Rees, F. Venter, T. Palanee), Contract Laboratory Services, Johannesburg Hospital, Johannesburg (W. Stevens, C. Ingram, M. Majam, M. Papathanasopoulos). Kwazulu-Natal: HIV-1 Prevention Unit, Medical Research Council, Durban (G. Ramjee, S. Gappoo, J. Moodley, A. Premrajh, L. Zako). Uganda: Medical Research Council/Uganda Virus Research Institute, Entebbe (H. Grosskurth, A. Kamali, P. Kaleebu, U. Bahemuka, J. Mugisha*, H.F. Njaj*). Spain: Hospital Clinic-IDIBAPS, University of Barcelona, Barcelona (J.M. Miro, M. Lopez-Dieguez*, C. Manzardo, J.A. Arnaiz, T. Pumarola, M. Plana, M. Tuset, M.C. Ligero, M.T. Garca, T. Gallart, J.M. Gatell). UK and Ireland: Royal Sussex County Hospital, Brighton (M. Fisher, K. Hobbs, N. Perry, D. Pao, D. Maitland, L. Heald), St James's Hospital, Dublin (F. Mulcahy, G. Courtney, S. O'Dea, D. Reidy), Regional Infectious Diseases Unit, 
Western General Hospital and Genitourinary Dept, Royal Infirmary of Edinburgh, Edinburgh (C. Leen, G. Scott, L. Ellis, S. Morris, P. Simmonds), Chelsea and Westminster Hospital, London (B. Gazzard, D. Hawkins, C. Higgs), Homerton Hospital, London (J. Anderson, S. Mguni), Mortimer Market Centre, London (I. Williams, N. De Esteban, P. Pellegrino, A. Arenas-Pinto, D. Cornforth*, J. Turner*), North Middlesex Hospital (J. Ainsworth, A. Waters), Royal Free Hospital, London (M. Johnson, S. Kinloch, A. Carroll, P. Byrne, Z. Cuthbertson), Barts \& the London NHS Trust, London (C. Orkin, J. Hand, C. De Souza), St Marys Hospital, London (J. Weber, S. Fidler, E. Hamlyn, E. Thomson*, J. Fox*, K. Legg, S. Mullaney*, A. Winston, S. Wilson, P. Ambrose), Birmingham Heartlands Hospital, Birmingham (S. Taylor, G. Gilleran). Imperial College Trial Secretariat: S. Keeling, A. Becker. Imperial College DSMC Secretariat: C. Boocock. (* Left the study team before the trial ended.).

\section{Conflicts of interest}

There are no conflicts of interest.

\section{References}

1. Churchill MJ, Deeks SG, Margolis DM, Siliciano RF, Swanstrom R. HIV reservoirs: what, where and how to target them. Nat Rev Microbiol 2016; 14:55-60.

2. Kandathil AJ, Sugawara S, Balagopal A. Are T cells the only HIV1 reservoir? Retrovirology 2016; 13:86.

3. Strain MC, Little SJ, Daar ES, Havlir DV, Gunthard HF, Lam RY, et al. Effect of treatment, during primary infection, on establishment and clearance of cellular reservoirs of HIV-1. I Infect Dis 2005; 191:1410-1418.

4. Jain $V$, Hartogensis $W$, Bacchetti $P$, Hunt PW, Hatano $H$, Sinclair E, et al. Antiretroviral therapy initiated within 6 months of HIV infection is associated with lower T-cell activation and smaller HIV reservoir size. I Infect Dis 2013; 208:1202-1211.

5. Hocqueloux L, Avettand-Fenoel V, Jacquot S, Prazuck T, Legac E, Melard A, et al. Long-term antiretroviral therapy initiated during primary HIV-1 infection is key to achieving both low HIV reservoirs and normal T cell counts. I Antimicrob Chemother 2013; 68:1169-1178.

6. Saez-Cirion A, Bacchus C, Hocqueloux L, Avettand-Fenoel V, Girault I, Lecuroux C, et al. Posttreatment HIV-1 controllers with a long-term virological remission after the interruption of early initiated antiretroviral therapy ANRS VISCONTI Study. PLoS Pathog 2013; 9:e1003211.

7. Henrich TJ, Hanhauser E, Marty FM, Sirignano MN, Keating S, Lee $\mathrm{TH}$, et al. Antiretroviral-free HIV-1 remission and viral rebound after allogeneic stem cell transplantation: report of 2 cases. Ann Intern Med 2014; 161:319-327.

8. Martin GE, Gossez M, Williams JP, Stohr W, Meyerowitz J, Leitman EM, et al. Posttreatment control or treated controllers? Viral remission in treated and untreated primary HIV infection. AIDS 2017; 31:477-484.

9. Deeks SG. HIV: shock and kill. Nature 2012; 487:439-440.

10. Ananworanich J, Gayet-Ageron A, Le Braz M, Prasithsirikul W, Chetchotisakd P, Kiertiburanakul S, et al. CD4-guided scheduled treatment interruptions compared with continuous therapy for patients infected with HIV-1: results of the Staccato randomised trial. Lancet 2006; 368:459-465.

11. Danel C, Moh R, Minga A, Anzian A, Ba-Gomis O, Kanga C, et al. CD4-guided structured antiretroviral treatment interruption strategy in HIV-infected adults in west Africa (Trivacan ANRS 1269 trial): a randomised trial. Lancet 2006; 367:1981-1989.
12. Strategies for Management of Antiretroviral Therapy Study Group. El-Sadr WM, Lundgren J, Neaton JD, Gordin F, Abrams D, Neaton JD. CD4+ count-guided interruption of antiretroviral treatment. N Engl J Med 2006; 355:2283-2296.

13. Fidler S, Porter K, Ewings F, Frater J, Ramjee G, et al. Shortcourse antiretroviral therapy in primary HIV infection. $\mathrm{N} \mathrm{Eng//}$ Med 2013; 368:207-217.

14. Williams JP, Hurst J, Stohr W, Robinson N, Brown H, Fisher M, et al. HIV-1 DNA predicts disease progression and posttreatment virological control. Elife 2014; 3:e03821.

15. Hurst J, Hoffmann M, Pace M, Williams JP, Thornhill J, Hamlyn $\mathrm{E}$, et al. Immunological biomarkers predict HIV-1 viral rebound after treatment interruption. Nat Commun 2015; 6:8495.

16. Li JZ, Etemad B, Ahmed H, Aga E, Bosch RJ, Mellors JW, et al. The size of the expressed HIV reservoir predicts timing of viral rebound after treatment interruption. AIDS 2016; 30:343-353.

17. Fidler S, Olson AD, Bucher HC, Fox J, Thornhill J, Morrison C, et al. Virological blips and predictors of post treatment viral control after stopping ART started in primary HIV infection. / Acquir Immune Defic Syndr 2017; 74:126-133.

18. WHO. Consolidated guidelines on the use of antiretroviral drugs for treating and preventing HIV infection. Recommendations for a public health approach. 2nd ed. 2016. http:/ www.who.int/hiv/pub/arv/arv-2016/en/. [Accessed 10 August 2018]

19. Frater J. The impact of HIV-1 subtype on the clinical response on HAART. I HIV Ther 2002; 7:92-96.

20. Lewden C, Thiebaut R, Boufassa F, Coulibaly A, Malateste K, Seng R, et al. Comparison of early CD4 T-cell count in HIV-1 seroconverters in Cote d'Ivoire and France: the ANRS PRIMOCI and SEROCO cohorts. I Acquir Immune Defic Syndr 2010; 53:260-265.

21. Iordanskiy S, Waltke M, Feng Y, Wood C. Subtype-associated differences in HIV-1 reverse transcription affect the viral replication. Retrovirology 2010; 7:85

22. de Oliveira T, Engelbrecht S, Janse van Rensburg E, Gordon M, Bishop K, zur Megede J, et al. Variability at human immunodeficiency virus type 1 subtype $C$ protease cleavage sites: an indication of viral fitness? J Virol 2003; 77:9422-9430.

23. Ball SC, Abraha A, Collins KR, Marozsan AJ, Baird H, QuinonesMateu ME, et al. Comparing the ex vivo fitness of CCR5-tropic human immunodeficiency virus type 1 isolates of subtypes B and C. J Virol 2003; 77:1021-1038.

24. Renjifo B, Gilbert P, Chaplin B, Msamanga G, Mwakagile D, Fawzi W, et al. Preferential in-utero transmission of HIV-1 subtype $\mathbf{C}$ as compared to HIV-1 subtype A or D. AIDS 2004; 18:1629-1636.

25. Taylor BS, Hammer SM. The challenge of HIV-1 subtype diversity. N Engl / Med 2008; 359:1965-1966.

26. Lynch RM, Shen T, Gnanakaran S, Derdeyn CA. Appreciating HIV type 1 diversity: subtype differences in Env. AIDS Res Hum Retroviruses 2009; 25:237-248.

27. Jones M, Williams J, Gartner K, Phillips R, Hurst J, Frater J. Low copy target detection by Droplet Digital PCR through application of a novel open access bioinformatic pipeline, 'definetherain'. I Virol Methods 2014; 202:46-53.

28. Liszewski MK, Yu JJ, O'Doherty U. Detecting HIV-1 integration by repetitive-sampling Alu-gag PCR. Methods 2009; 47:254-260.

29. Lewin SR, Vesanen M, Kostrikis L, Hurley A, Duran M, Zhang L, et al. Use of real-time PCR and molecular beacons to detect virus replication in human immunodeficiency virus type 1infected individuals on prolonged effective antiretroviral therapy. J Virol 1999; 73:6099-6103.

30. Pasternak AO, Adema KW, Bakker M, Jurriaans S, Berkhout B, Cornelissen $M$, et al. Highly sensitive methods based on seminested real-time reverse transcription-PCR for quantitation of human immunodeficiency virus type $\mathbf{1}$ unspliced and multiply spliced RNA and proviral DNA. / Clin Microbiol 2008; 46:2206-2211.

31. Kiepiela P, Leslie AJ, Honeyborne I, Ramduth D, Thobakgale C, Chetty $S$, et al. Dominant influence of HLA-B in mediating the potential co-evolution of HIV and HLA. Nature 2004; 432:769-775.

32. Frater J, Ewings $\mathrm{F}$, Hurst J, Brown $\mathrm{H}$, Robinson $\mathrm{N}$, Fidler $\mathrm{S}$, et al. HIV-1-specific CD4 $(+)$ responses in primary HIV-1 infection predict disease progression. AIDS 2014; 28:699-708.

33. Friendly M. Corrgrams: exploratory displays for correlation matrices. Am Stat 2002; 56:316-324. 
34. Fellay J, Shianna KV, Ge D, Colombo S, Ledergerber B, Weale $\mathrm{M}$, et al. A whole-genome association study of major determinants for host control of HIV-1. Science 2007; 317:944-947.

35. Huang KH, Goedhals D, Carlson JM, Brockman MA, Mishra S, Brumme ZL, et al. Progression to AIDS in South Africa is associated with both reverting and compensatory viral mutations. PLoS One 2011; 6:e19018.

36. Matthews PC, Adland E, Listgarten J, Leslie A, Mkhwanazi N, Carlson JM, et al. HLA-A $* 7401$-mediated control of HIV viremia is independent of its linkage disequilibrium with HLAB $*$ 5703. J Immunol 2011; 186:5675-5686.

37. Stohr W, Fidler S, McClure M, Weber J, Cooper D, Ramjee G, et al. Duration of HIV-1 viral suppression on cessation of antiretroviral therapy in primary infection correlates with time on therapy. PLOS One 2013; 8:e78287.

38. Kassu A, Tsegaye A, Petros B, Wolday D, Hailu E, Tilahun T, et al. Distribution of lymphocyte subsets in healthy human immunodeficiency virus-negative adult Ethiopians from two geographic locales. Clin Diagn Lab Immunol 2001; 8:1171-1176.

39. Touloumi G, Pantazis N, Pillay D, Paraskevis D, Chaix ML, Bucher HC, et al. Impact of HIV-1 subtype on CD4 count at HIV seroconversion, rate of decline, and viral load set point in European seroconverter cohorts. Clin Infect Dis 2013; 56:888-897.

40. Tollerud DJ, Clark JW, Brown LM, Neuland CY, Pankiw-Trost $\mathrm{LK}$, Blattner WA, et al. The influence of age, race, and gender on peripheral blood mononuclear-cell subsets in healthy nonsmokers. J Clin Immunol 1989; 9:214-222.

41. Delmas MC, Jadand C, De Vincenzi I, Deveau C, Persoz A, Sobel A, et al. Gender difference in CD4+ cell counts persist after HIV-1 infection. SEROCO Study Group. AIDS 1997; 11:1071-1073.

42. CASCADE Collaboration. Differences in CD4 cell counts at seroconversion and decline among 5739 HIV-1-infected individuals with well estimated dates of seroconversion. J Acquir Immune Defic Syndr 2003; 34:76-83.

43. Sterling TR, Lyles CM, Vlahov D, Astemborski J, Margolick JB, Quinn TC. Sex differences in longitudinal human immunodeficiency virus type 1 RNA levels among seroconverters. / Infect Dis 1999; 180:666-672.

44. Napravnik S, Poole C, Thomas JC, Eron JJ Jr. Gender difference in HIV RNA levels: a meta-analysis of published studies. J Acquir Immune Defic Syndr 2002; 31:11-19.

45. Touloumi G, Pantazis N, Babiker AG, Walker SA, Katsarou O, Karafoulidou A, et al. Differences in HIV RNA levels before the initiation of antiretroviral therapy among 1864 individuals with known HIV-1 seroconversion dates. AIDS 2004; 18:1697-1705.

46. Gray CM, Williamson C, Bredell H, Puren A, Xia X, Filter R, et al. Viral dynamics and CD4+ $\mathbf{T}$ cell counts in subtype $C$ human immunodeficiency virus type 1 -infected individuals from southern Africa. AIDS Res Hum Retroviruses 2005; 21:285-291.

47. Vasan A, Renjifo B, Hertzmark E, Chaplin B, Msamanga G, Essex $M$, et al. Different rates of disease progression of HIV type 1 infection in Tanzania based on infecting subtype. Clin Infect Dis 2006; 42:843-852.

48. Klein MB, Young J, Dunn D, Ledergerber B, Sabin C, CozziLepri A, et al. The effects of HIV-1 subtype and ethnicity on the rate of $\mathrm{CD} 4$ cell count decline in patients naive to antiretroviral therapy: a Canadian-European collaborative retrospective cohort study. CMAJ Open 2014; 2:E318-E329.
49. Rinke de Wit TF, Tsegaye A, Wolday D, Hailu B, Aklilu M, Sanders E, et al. Primary HIV-1 subtype C infection in Ethiopia. J Acquir Immune Defic Syndr 2002; 30:463-470.

50. Minga AK, Anglaret X, d' Aquin Toni T, Chaix ML, Dohoun L, Abo Y, et al. HIV-1 DNA in peripheral blood mononuclear cells is strongly associated with HIV-1 disease progression in recently infected West African adults. I Acquir Immune Defic Syndr 2008; 48:350-354.

51. Novitsky V, Woldegabriel E, Kebaabetswe L, Rossenkhan R, Mlotshwa B, Bonney C, et al. Viral load and CD4+ T-cell dynamics in primary HIV-1 subtype C infection. I Acquir Immune Defic Syndr 2009; 50:65-76.

52. Eggena MP, Barugahare B, Okello M, Mutyala S, Jones N, Ma Y, et al. T cell activation in HIV-seropositive Ugandans: differential associations with viral load, CD4+ T cell depletion, and coinfection. J Infect Dis 2005; 191:694-701.

53. Rouzioux C, Hubert JB, Burgard M, Deveau C, Goujard C, Bary $M$, et al. Early levels of HIV-1 DNA in peripheral blood mononuclear cells are predictive of disease progression independently of HIV-1 RNA levels and CD4+ T cell counts. / Infect Dis 2005; 192:46-55.

54. Kostrikis LG, Touloumi G, Karanicolas R, Pantazis N, Anastassopoulou C, Karafoulidou A, et al. Quantitation of human immunodeficiency virus type 1 DNA forms with the second template switch in peripheral blood cells predicts disease progression independently of plasma RNA load. / Virol 2002; 76:10099-10108.

55. Goujard C, Bonarek M, Meyer L, Bonnet F, Chaix ML, Deveau $C$, et al. CD4 cell count and HIV DNA level are independent predictors of disease progression after primary HIV type 1 infection in untreated patients. Clin Infect Dis 2006; 42:709 715.

56. Liovat AS, Rey-Cuille MA, Lecuroux C, Jacquelin B, Girault I, Petitjean $\mathrm{G}$, et al. Acute plasma biomarkers of T cell activation set-point levels and of disease progression in HIV-1 infection. PLoS One 2012; 7:e46143.

57. Giorgi JV, Hultin LE, McKeating JA, Johnson TD, Owens B, Jacobson LP, et al. Shorter survival in advanced human immunodeficiency virus type $\mathbf{1}$ infection is more closely associated with $\mathrm{T}$ lymphocyte activation than with plasma virus burden or virus chemokine coreceptor usage. J Infect Dis 1999; 179:859-870.

58. Hazenberg MD, Otto SA, van Benthem BH, Roos MT, Coutinho RA, Lange JM, et al. Persistent immune activation in HIV-1 infection is associated with progression to AIDS. AIDS 2003; 17:1881-1888.

59. Hoffmann M, Pantazis N, Martin GE, Hickling S, Hurst J, Meyerowitz J, et al. Exhaustion of activated CD8 T cells predicts disease progression in primary HIV-1 infection. PLOS Pathog 2016; 12:e1005661.

60. Muller $\mathrm{V}$, von Wyl $\mathrm{V}$, Yerly S, Boni J, Klimkait T, Burgisser $\mathrm{P}$, et al. African descent is associated with slower CD4 cell count decline in treatment-naive patients of the Swiss HIV Cohort Study. AIDS 2009; 23:1269-1276.

61. Pantazis N, Morrison C, Amornkul PN, Lewden C, Salata RA, Minga $A$, et al. Differences in HIV natural history among African and non-African seroconverters in Europe and seroconverters in sub-Saharan Africa. PLOS One 2012; 7:e32369.

62. Rouzioux C, Hocqueloux L, Saez-Cirion A. Posttreatment controllers: what do they tell us?. Curr Opin HIV AIDS 2015; 10:29-34. 